\title{
Pedagogik med inriktning mot yngre barns utveckling och lärande
}

\author{
Ingegerd Tallberg Broman
}

The professorship I held was denoted "Pedagogy with a focus on the development and learning of younger children". It was a newly instituted professorship at the Teacher Education Program at the newly founded university college in Malmö. The purpose was dual - to further develop research related to children's development and learning in pre-school as well as to contribute to the academization of the pre-school teacher education. It was initiated by the director of the Teacher Education Program, and was placed at the department responsible for preschool teacher education. In this article, the professorship's purpose and orientation will be discussed in a historical perspective. It considers significant aspects of the development of the program for pre-school education, such as practical pedagogy, knowledge traditions, and gender. In addition, it suggests that the development of this program was characterized by a complicated relationship to the state as well as the academy, involving efforts to reconcile both sides. The article also discusses the late nationalization of this program and why a professorship was established in 1999 to support research and academic development. Other themes discussed, with examples from my own work as researcher, expert, and teacher, are the terms and conditions of the research area, special initiatives, and continuity and discontinuity.

\section{LÄRARUTBILDNING MOT YNGRE BARN}

Den professur jag innehaft betecknades "Pedagogik med inriktning mot yngre barns utveckling och lärande". Den var en nyinrättad professur på lärarutbildningen på den nya högskolan i Malmö. Den hade dubbelt syfte att vidareutveckla forskning knuten till inriktningen, och att bidra till akademisering av utbildning mot arbete som förskollärare. Den initierades av 
ansvarig för lärarutbildningen, Olle Holmberg ${ }^{-1}$ och var placerad på den enhet som ansvarade för utbildningen. Det skilde den från övriga professurer i pedagogik, som var samlade på den pedagogiska institutionen.

Ett historiskt perspektiv på förskola och förskollärarutbildningar ska inledningsvis ge underlag för förståelse av bakgrunden till min professur. Sett över tid framkommer tydliga tecken på "path-dependancy", som Myles och Pierson (2001) formulerade det: "Processes in which choices made in the past systematically constrain the choices open in the future" (Mylew \& Pierson, 2001, s. 306). I det historiska perspektivet är det framför allt den föreställda platsen i Lefebvres (1991) mening som beskrivs, det vill säga "the conceived place". "Platsen" det sociala rummet förskola och förskollärarutbildning innefattar såväl materiella, mentala som sociala dimensioner och ett spänningsförhållande mellan nivåerna "conceived", "perceived" och "lived" (Persson \& Tallberg Broman, 2017, 2018; Tallberg Broman, 1991).

Förskolan formulerades historiskt som en modernitetsinstitution, med tydliga normativa ambitioner, genom vilken ett bättre samhälle skulle formas genom pedagogik och uppfostran. I de tidiga Fröbelinspirerade verksamheterna framhölls värden kopplade till natur, familj, hembygd och hälsa. Senare tider uppmärksammade tema som fred, demokrati och social kompetens/ livskunskap (Dahlbeck \& Tallberg Broman, 2011; Löf, 2011). I nutiden fokuseras i ökande grad hållbar utveckling (UNESCO, 2007), men också åter hälsa, nu kopplat till livsstil, som uttrycker det ökande egenansvaret (Trondman, 2009). Den internationella prägeln och det högre syfte än enbart omsorg, utveckling och lärande var utmärkande för den fröbelsinspirerade tidiga förskolan i Sverige, liksom i övriga Norden (Korsvold, 2008).

Inflytandet från Fröbeltraditionen var framträdande vid de första seminarierna för de blivande förskollärarna. Seminarierna var närmast ett utryck för denna tradition, och med den synen på utbildning, barn, barndom, bildning och lärande. Fröbels (1892) pedagogik var influerad av Comenius (1892) om hur människans utbildning bäst sker i barnåren och egentligen endast då kan genomföras. Den var också påverkad av Rousseaus (1892) framställning om barndomens egenvärde och om barnet och barndomen som något avskilt. Kanske var dock inflytandet från Pestalozzi (1890) det mest betydelsefulla för framväxten av "rörelsen för ny fostran och bildning", som Hammarström-Lewenhagen (2016, s.19) sammanfattar det, och med detta tilltron till folkutbildning för alla, flickor som pojkar och av alla sociala klasser.

Efter de första decennierna av förskollärarutbildning, ännu i mycket blygsamt antal studerande, kom 1930-talet att innebära nya influenser. Den tyska och centraleuropeiska dominansen bröts till förmån för mer anglosaxisk påverkan och psykologisk teoribildning. Nya seminarier startar i Stockholm, och psykologi, särskilt utvecklingspsykologi, blev hjälpvetenskap och den vetenskapliga grunden till utvecklingen av den pedagogiska verksamheten och 
förskolläraryrket. Med psykologin ställs barnet och dess utveckling i olika stadier $\mathrm{i}$ fokus. Det barnpsykologiska barnet tar form, och blir en framträdande aspekt av förståelsen av barn och barndom med påverkan på förskola och förskolepedagogik. Tiden för min professur kom att innefatta ett påtagligt brott mot denna tradition, med nya teoretiska influenser och en förändrad ställning för barnet.

Alva Myrdal, som startade Socialpedagogiska seminariet i Stockholm, framhöll vetenskapen som ledstjärna och förespråkade en småbarnspedagogik på den psykologiska vetenskapens grund. Vid Socialpedagogiska seminariet gavs en grundlig undervisning inom den utvecklingspsykologiska och inlärningspsykologiska forskningen. Alva Myrdal drev också tanken att universitetsutbildningen skulle vara förebilden för förskollärarutbildningen. Den psykologiska vetenskapen kom att utgöra en tydlig referenspunkt i förskollärarutbildningen och för den framväxande förskolepedagogiska forskningen (Rubinstein Reich, 2017). Som underlag för en pedagogisk verksamhet var den dock komplicerad. Den Fröbelinspirerade metodiken, kombinerad med en barnpsykologisk förståelse av barnet, återspeglas många år framöver (Tallberg Broman, 1991).

\section{Förskollärarutbildning, kön och isärhållning}

Kvinnor var länge utestängda från den offentliga kulturen, det politiska livet och dess förberedande institutioner, som exempelvis läroverken. Detta gav grogrund för utvecklingen av en sidoordnad rikt förgrenad social sfär som utvecklade utbildnings-, vård- och omsorgstraditioner och institutioner under slutet av 1800-talet och början av 1900-talet. Inom alternativa utbildningar, framför allt för flickor/kvinnor, utprövades reformpedagogiska idéer och lärandeformer. De blev pedagogiska rum för nya tankar inom utbildning och lärande. Könsgränsen var markerad och den var en förutsättning för vidgandet av det sociala rummet för både eleverna, de kvinnliga lärarna och utbildningsledarna. Seminarieutbildningarna inom förskolans område riktade sig också under de första decennierna uteslutande till kvinnor. Få kontakter fanns med den akademiska världen och med discipliner som pedagogik under 1900-talets första hälft, en tid då akademin i hög grad var en manlig värld.

I den tidiga förskollärarutbildningen hade praktikgrundade kunskaper, konstnärliga ämnen och ämnesintegrerade studier en framträdande position. Ett drag av "path- dependancy" kan påtalas, vad gäller såväl positionering som innehåll samt förhållande till akademi och stat, i så motto att förskollärarutbildning - och förskola - länge initierades, genomfördes och utvecklades utanför stat och akademi. Professionen har haft ett starkt inflytande, med hög grad av autonomi och kontroll, utanför statlig styrning och reglerande riktlinjer - och tydligt arbetat för att bevara denna vid de många kommande inordningarna i större nationella system. Upplevelser av 
minskad autonomi och kontroll, och stora skillnader mellan dimensionerna "conceived", "perceived" och "lived" (Lefebvre, 1991) vad gäller förskoleprofessionen, med otillräcklighetskänslor och stressjukdomar som följd, uttrycks i våra nutidsinriktade studier (Persson \& Tallberg Broman, 2002, 2015, 2017).

\section{Förskollärarutbildningen, staten och utredningarna}

Flickors/kvinnors utbildning liksom omvårdnad och fostran av de yngsta barnen uppfattades inte vara statens uppgift, det var familjens ansvar. Statens stöd till förskola och förskollärarutbildning var följaktligen länge mycket begränsat. Förstatligandet av seminarierna var också mycket sent $\mathrm{i}$ förhållande till andra lärarseminarier/utbildningar. Redan med 1842 års stadga för folkundervisningen etablerades folkskollärarutbildningen som ett statligt ansvarsområde. (SFS 1842:19). Genom 1931 års riksdagsbeslut omfattades även småskollärarutbildningen av förstatligande. Fram till 1945 hade förskollärarutbildningarna inget statligt stöd. Ekonomin baserades på framför allt privat ekonomi, samt stöd från stiftelser, intresseorganisationer och av mindre bidrag från kommunerna.

En särskild delegation tillsattes 1949 för att utreda lärarutbildningen. Denna delegation presenterade sitt förslag 1952. Förutom speciallärare skulle tre kategorier utbildas: småskollärare för lågstadiet, mellanskollärare för mellanstadiet, ämneslärare för högstadiet och gymnasieskolan. Däremot sågs det som omöjligt att även inordna förskollärarutbildningen $\mathrm{i}$ detta system. Förskollärarseminariernas ledningar var också skeptiska. Här illustreras gränsdragning, en form av upprätthållande av gränser och distans från båda håll. Ett inordnande skulle kräva, uppfattades det, att de arbetssätt och kunskapstraditioner som var kännetecknande för förskollärarutbildningen hotades. Från utredarnas håll uttrycks över tid tveksamhet både om utbildningarnas kvalité, dess praktiska inriktning och till detta en tveksamhet om det de syftade till - det vill säga institutioner för små barn utanför hemmet. Vi ser såväl historiskt som i nutiden en form av ömsesidigt gränsarbete, "boundary work" med Gieryns (1983) terminologi. Ett inordnande kom dock att bli nödvändigt för att trygga seminariernas fortbestånd ekonomiskt, men det kopplades till garantier om att utbildningarnas uppläggning och arbetsformer skulle kunna bibehållas (SOU 2008:109 s. 76). Utredningarna har sedan mitten av 1900-talet varit flertaliga. Här ska tre exempel ges, som visar såväl på kontinuitet som brott i positioneringen av utbildningen, genom SOU 1960:33, SOU 1975:67 och SOU 2008:109.

1958 års förskollärarutredning föreslog i sitt betänkande (SOU 1960:33) ett förstatligande av förskollärarutbildningen. Den 9 maj 1962 beslutade så riksdagen om ett nytt statligt seminarium, och att detta första skulle starta i Malmö under kommande budgetperiod. Dock anger man àterballsambet - 
utbildningen ledde till en verksamhet som det förelåg tveksamhet till. Utredningarna om, och synen på, förskollärarutbildningen och statens ansvar och engagemang ska ses i förhållande till vad utbildningen leder till och till den grupp som utbildas.

1968 års barnstugeutredning, motsvarade en kommitté som mellan åren 1960-1975 genomförde fyra utredningar, och skapade underlag för såväl en utbyggd förskola (SOU 1972: 26-27) som förskollärarutbildning (SOU 1975:67). Politisk konsensus förelåg för utbyggnad, och den motiverades brett av både arbetsmarknads- och jämställdhetsskäl, förutom av de tidigare barnpedagogiska och familjepolitiska grunderna.

\section{En hållbar lärarutbildning och utbildning till förskollärare}

Den 20 juni 2007 fattade regeringen beslut att tillsätta en särskild utredare för att lämna förslag till en ny lärarutbildning. Under hösten 2007 knöts en expertgrupp till den senaste utredningen, $i$ vilken jag hade förmånen att delta. I regeringens direktiv (Dir. 2007:103) angavs:

En utredare ska utifrån förskolans, fritidshemmets och skolans mål och behov av lärarkompetens lämna förslag till en ny lärarutbildning. Förslaget ska innefatta lärarutbildningens mål, innehåll, struktur, omfattning, dimensionering och styrning. Utredaren ska överväga om det inom ramen för lärarutbildningen bör införas egna examina för olika inriktningar ... Utredaren ska föreslå hur forskningsanknytningen av lärarutbildningen, dess koppling såväl till utbildningsvetenskap som till ämnesteori och ämnesdidaktik, kan förbättras och hur antalet forskarutbildade lärare kan öka samt hur resultat av den praxisnära forskningen ska komma skolan till del (SOU 2008:109, s. 453).

Vidare angavs att:

Förskolan skall erbjuda barnen en god pedagogisk verksamhet, där omsorg, fostran och lärande bildar en helhet. Förskolläraren skall främja barnens lust att lära samt lägga grunden för barnens lärande och fortsatta skolgång. För att fördjupa det pedagogiska uppdraget behöver kompetensen hos förskollärare stärkas (SOU 2008:109, s. 454).

Detta syntes mycket angeläget. Både förbättrad forskningsanknytning och stärkande av förskollärarnas kompetens som uttrycks i direktiven var också, då som nu, av mycket stor vikt, och helt $\mathrm{i}$ linje med min professurs uppdrag.

Utredningen, som var en ensamutredning med en expertgrupp knuten till sig, föreslog sammanfattningsvis: 
Efter analys av kompetensbehovet föreslår utredningen att grundlärarutbildningen med inriktning på förskolan blir treårig, med möjlighet till ett års påbyggnadsutbildning för fördjupning till undervisning i förskoleklassen. Som framgår av kompetensanalysen i kapitel 3.3.2 ställer förskoleklassen lärarna inför särskilda utmaningar som inte täcks av innehållet $i$ den treåriga förskollärarutbildningen. Påbyggnadsåret kan läsas direkt efter den treåriga utbildningen eller efter en tids yrkesverksamhet (SOU 2008: 109, s. 321).

Detta var ett problematiskt avslut på arbetet i denna grupp knuten till lärarutbildningsutredning. Diskussionen hade pendlat mellan olika alternativ. För mig som sakkunnig vad gäller förskollärarutbildning och med professur att verka för dess akademisering och förstärkning av den vetenskapliga basen, och med omfattande kännedom om relationen mellan kvalité i förskolans verksamhet och personalens utbildningsnivå, var det ett synnerligen bekymmersamt förslag.

Det kom dock inte att genomföras. ${ }^{2}$ Påbyggnadsåret kom heller inte att möjliggöras, inte ännu. Det är, och var, dock ett angeläget förslag, inriktat på fördjupning för undervisning i förskoleklassen, som också öppnar för vidare forskarstudier. I förskoleklassen, som från hösten 2018 är obligatorisk, arbetar huvudsakligen förskollärare. I förskollärarutbildningen utbildas man dock till förskolan, och utifrån förskolans läroplan. Utredningens förslag var här både framsynt och i stort behov av förverkligande. Givet kan ett fördjupningsår/termin också tänkas med flera andra angelägna inriktningar.

\section{Förskollärarutbildningen och akademin - den praktiska pedagogiken}

Pedagogik knutet till lärarutbildning, liksom lärarutbildningen i sig själv, sågs länge som praktisk. Professuren vid den första lärarhögskolan i Sverige, Lärarhögskolan i Stockholm, fick också benämningen praktisk pedagogik. Den innehades vid starten av professor Torsten Husén. ${ }^{3}$ Vid Lunds universitet delades pedagogikämnet $\mathrm{i}$ ett mer teoretiskt inriktat som hade säte $\mathrm{i}$ Lund $^{4}$ och ett där benämningen på den nyinrättade professuren blev praktisk pedagogik. Den placerades vid lärarhögskolan i Malmö, och kom att innehas av professor Åke Bjerstedt från starten 1962 till år 1995. Lärarhögskolan i Malmö var en del av Lunds universitet, men placerad två mil sydväst i dåvarande industristaden Malmö. I Göteborg återfinns från 1965 Institutionen för praktisk pedagogik som en del av Lärarhögskolan fram till år 1984, då den slås samman med Pedagogiska institutionen.

Det praktiska skulle hållas på avstånd från det teoretiska, det vetenskapliga. Pedagogikämnet hade i kommentarerna kring inrättandet av en första professur i pedagogik i början av 1900-talet kritiserats för att inte vara "en 
färdigbildad vetenskap" som omfattade en "mängd starkt heterogena element" (Lindberg \& Berge, 1988 s. 18) och det var viktigt att värna om dess ställning och dess gränser.

Professorerna i pedagogik skulle, för att citera rektorn vid Lunds universitet Axel Moberg, ha som "sin förnämsta uppgift att arbeta på sin vetenskaps fortsatta utveckling". Han framhöll att det var lyckligt, att den planerade kopplingen mellan en ny professur i pedagogik i Lund och den praktiska undervisningsverksamheten i form av övningsskola, inte kom till stånd (Lindberg \& Berge, 1988, s. 22). Som anmärkning kan noteras att dåvarande universitetsrektorn Axel Moberg var bror till initiativtagarna till det mest inflytelserika av de första förskollärarseminarierna, Fröbelinstitutet, det vill säga till Ellen Moberg och Maria Moberg. De senare bidrog starkt till grunden för det svenska förskolesystemet, inklusive praktisk förskolepedagogik och övningsskolor kopplade till seminarieutbildningarna.

Dessa två utbildningsvärldar, seminarierna och akademin, kännetecknades av skilda kunskaps- och bildningstraditioner, könssammansättning samt förhållande till staten. Det utgör förhållanden som har präglat, och kontinuerligt, om än kanske något mindre framträdande, präglar, förutsättningarna för förskola, förskollärarutbildning och förskoleforskning samt för min professurs inriktning.

Pedagogikämnet har $i$ huvudsak varit förskoleforskningens och förskollärares akademiska hemvist fram till dagens mer mångfaldiga akademiska landskap, med fler möjligheter för utveckling av professions- och verksamhetsnära forskning. Det var på pedagogikinstitutioner knutna till lärarutbildningar, som den förskolrelaterade forskningen förekom visar Bjerstedt (1999) i en genomgång av pedagogikavhandlingar publicerade åren 1969-1998.

På de pedagogikinstitutioner som saknade koppling till lärarutbildning, förekom i liten utsträckning forskning som behandlade förskoleåldern, förskola och förskolläraryrket. Under senare år har här skett ett brott, med flera nya ämnen och genom att avgränsade delar av pedagogiken inrättats som nya discipliner. Forskning om yngre åldrar respektive förskola återfinns i dag inom flera andra ämnen, som Barn- och ungdomsvetenskap, Pedagogiskt arbete och Förskoledidaktik. Pedagogikämnet utgör nu också ett av flera inom det utbildningsvetenskapliga området, så också vid Malmö universitet, med förändrade förutsättningar.

\section{Att akademisera och stärka den vetenskapliga grunden}

Den professur jag nu lämnat skulle verka för akademisering av förskollärarutbildningen och att stärka forskning relaterad till utbildningens huvudämne. Detta tema kan sägas ha varit både framträdande och återkommande framför allt sedan högskolereformen 1977. Denna föregicks för förskolans del av 
barnstugeutredningens betänkanden SOU 1972:26-27 och SOU 1975:67. 1977 blev förskollärarutbildningen, liksom många professionsutbildningar, en högskoleutbildning genom högskolereformen. Samma argument framhålls också i denna reform. Kopplingen mellan utbildning och forskning skulle bli starkare för att bland annat bidra till att minska problemen i skolan och att förbättra resultaten.

Redan i utredningen om den första lärarhögskolan (SOU 1952:33) hade betydelsen av att stärka den vetenskapliga grunden $i$ lärarutbildningen framhävts. Detta motsvarades då främst av det pedagogiskt-psykologiska området. Vetenskap och försöksverksamhet skulle göra skolans undervisning både effektivare och bättre anpassad till målen (Linné, 2014). Argumentationen är påfallande lik den som anförs 62 år senare kring inrättandet av en ny myndighet med benämningen Skolforskningsinstitutet. ${ }^{5}$ Tilltron till forskningens möjligheter upprepas genom åren, liksom även besvikelserna över dess bristande relevans och uteblivna effekter.

Under senare år har den vetenskapliga grunden och vikten av forskning både framhävts, och även krävts. Det föreligger dock en konflikt mellan erfarenhets- och hantverkskunskap i förhållande till den kunskap som de vetenskapliga studierna kan bidra med, menar Agevall och Olofsson (2014). Kritiken mot forskningen, som irrelevant och som dåligt känd och etablerad i verksamheterna, har varit återkommande. Detta gäller hela skolområdet, så även förskolefältet. Det sker dock många utvecklingsinsatser inom området. En kartläggning av forskning om den svenska förskolan för åren 2006-2014 (Tallberg Broman, 2015) ${ }^{6}$ visade att i stort sett alla avhandlingsförfattare hade egen bakgrund i förskolan och/eller i dess lärarutbildning. Förutsättningarna syns goda för att denna forskning ska ha hög relevans, såväl för förskollärarprofessionen som för förskolans verksamhet. Problematiken med verksamheternas och professionernas delaktighet $\mathrm{i}$ forskningen har fångat mångårig uppmärksamhet och begreppen forskningsanknytning, forskningsbasering och praktiknära forskning är mycket återkommande i målsättningar för lärarutbildnings- och förskole/skolutveckling sedan lång tid (SOU 2018:19).

\section{FÖRSKOLE- OCH SKOLRELATERAD FORSKNING: STOR EFTERFRÅGAN - BEGRÄNSANDE VILLKOR}

Vid 20 lärosäten erbjuds förskollärarutbildningar av olika utformning i Sverige. Vid samtliga dessa, liksom vid lärarutbildningar inriktade mot andra skolformer, efterfrågas forskning och lyfts betydelsen av forskningsanknytning och av för utbildningarna relevant forskning vid det egna lärosätet. Den utbildningsvetenskapliga och ämnesdidaktiska forskningen kan dock inte sägas ha mött en mer omfattande satsning, vare sig lokalt i lärosätenas budgetar i förhållande till lärarutbildningarnas uppdrag och stora 
antal studenter, eller i den nationella budgeten i förhållande till andra vetenskapsområden.

Under några år, först som bedömare och sedan som medlem i utbildningsvetenskapliga kommittén ${ }^{7}$, blev de begränsade möjligheter som förelåg för att stärka den vetenskapliga grunden i såväl lärarutbildningarna som i de olika skolformerna tydligare för mig. Även skillnaden mellan lärosätena i att tillägna sig denna begränsade budget synliggjordes.

Vetenskapsrådets (2011a) kartläggning av utbildningsvetenskaplig forskning 2005-2010 visade att forskningen var koncentrerad till ett antal profilerade miljöer vid landets större lärosäten. Vid dessa bedrevs utbildningsvetenskaplig forskning också inom ett stort antal discipliner, medan den vid högskolorna främst bedrevs inom pedagogik och didaktik. Den kategori lärosäten som erhållit mest externa medel för utbildningsvetenskaplig forskning var de äldre universiteten (74\%), följt av yngre universitet, (10\%), och högskolor (9\%) (Vetenskapsrådet, 2011a, s. 26). Någon särskild koppling till lärarutbildningarnas forskningsanknytning är svår att utläsa. Nya direktiv om breddning av syftet kom också under Tobias Krantz tid som högskole- och forskningsminister:

Relevanskravet förändras. Man ska kunna tolka uppdraget lite friare. Den forskning som finansieras av utbildningsvetenskapliga kommittén ska bedrivas på ett sådant sätt att man kan skapa mer evidensbaserat arbete ute på universiteten. Det är en viktig inriktning, säger högskole- och forskningsminister Tobias Krantz (Lärarnas Tidning, 2010).

\section{Samarbeten för forskningsutveckling}

För utvecklingen av forskning inom professurens område har olika forskningssamarbeten varit av största betydelse. Här ska två exempel som representerar olika modeller för detta beskrivas. Den första innebar samarbete över lärosäten i ett större gemensamt projekt med ett antal delprojekt, där samtliga ingående i projektet arbetade inom den pedagogiska disciplinen.

Utbildningsvetenskapliga kommittén tillämpade under en tid en princip för medelstilldelning där det markerades som positivt att huvudsökande byggde in samarbeten med högskolor. Detta blev till en positiv möjlighet för oss på dåvarande Malmö högskola, och stimulerade till att jag blev inbjuden som medsökande till ett större och senare beviljat projekt: "Förändrade könsgenusordningar i skola och utbildning. Policy, perspektiv och praktik" (Wernersson, 2009). Projektet pågick 2003-2006 och innebar ett samarbete mellan forskare från Göteborgs universitet, Borås högskola, Umeå universitet och Malmö högskola. Det huvudsakliga arbetet i projektet genomfördes som doktorandprojekt, ett vid varje ingående lärosäte. Så skapades en arbetande forskningsmiljö över lärosäten och inom en och samma disciplin. Det skapade ett sammanhang för doktorandprojekten, som inte hade varit möjligt på det 
enskilda lärosätet, och stimulerade också framgångsrikt den seniora forskningen, med nya forskningssamarbeten som följd (Eilard, 2008, 2009; Tallberg Broman, 2009).

Det andra exemplet redovisar en modell för forskningssamarbete inom Malmö högskola. Utlysningen syftade till att stimulera framväxten av flervetenskapliga fakultetsövergripande forskningsmiljöer vid den unga högskolan. Så skapades en flerdisciplinär grupp, som jag ansvarade för, och som senare kom att erhålla ett större bidrag från Vetenskapsrådet för projektet "Mångkontextuell Barndom. Skola, fritid, familj i förändring och gränsöverskridande".

I projektet ingick forskare med bakgrund i rättssociologi, statsvetenskap, idrottsvetenskap, kultursociologi, etnologi, psykologi och pedagogik. Flervetenskapligheten utmanade vid högskolan/akademin existerande strukturer och regelverk. Det gav dock stora vinster och ny kunskap. Studierna belyste den gränsöverskridande skolan och den ökade regleringen av barndomen, $i$ och genom samverkan i barndomens olika sociala rum, här främst mellan skola, hem och idrott. Förändringen från betoning på rättigheter till framhävande av ansvar, och barn som egenansvariga självreglerande subjekt, tydligjordes i flera bidrag, summerade Trondman (2009) i sin slutkommentar till gruppens temanummer i tidskriften Educare (Tallberg Broman et al. 2009). I högskolans strävan efter profilering och utökning av forskningsverksamhet och forskningsmedel har denna form av lärosätesrelaterade utlysningar upprepats senare år. 2008 bildade vi bland annat det flerdisciplinära nätverket "Barndom och ungdom i förändring" kring teman som karakteriserat Malmö högskola, med begrepp som klass, kön, etnicitet, mångfald, likvärdighet och segregation och påbörjade centrumformering (Sernhede \& Tallberg Broman, 2011, 2014).

Dessa olika former av satsningar på den egna högskolans profilering och forskningsverksamhet har varit mer framträdande senare åren av min professur och fortsatta anställningstid. Detta har varit en ökande trend, med koncentration av forskningsmedel till några få forskningsstarka miljöer, med differentierade villkor för forskarna relaterat till forskningsframgång och anknytning till starka miljöer. Lärarutbildningarna har över tid inte varit påtagligt framgångsrika $\mathrm{i}$ denna konkurrens, med sina stora undervisningsuppdrag och mindre andel forskare, trots ett starkt behov av förstärkt vetenskaplig grund, givet också i lärosätets intresse.

\section{SÄRSKILDA SATSNINGAR}

Forskning inom området har varit beroende av och kunnat vidareutvecklats genom olika särskilda satsningar. Här ska två exempel redovisas. 


\title{
Förskoleforskning kopplat till förskola som tidig insats
}

\begin{abstract}
Vill man bygga en kunskapsnation börjar man i förskolan. Forskningen är entydig: effekterna av en förskola följer med barnen upp genom grundskola och vidare in $i$ vuxenlivet. OECD har kunnat redovisa att de $i$ Pisa-proven, som elever gör som 15-åringar, kan se effekten av en god pedagogisk förskola (Fridolin \& Hallengren, 2017, 31/3).
\end{abstract}

Så uttryckte sig Gustaf Fridolin (dåvarande utbildningsminister) och Lena Hallengren (dåvarande ordförande i riksdagens utbildningsutskott) i Svenska Dagbladet i mars 2017.

Inför uppstarten av Skolforskningsinstitutet initierades av Vetenskapsrådet ett antal forsknings/kunskapsöversikter, däribland Förskola tidig intervention, som jag ansvarade för och genomförde tillsammans med tre andra forskare från Malmö universitet (Tallberg Broman, Vallberg Roth, Palla, Persson, 2015), Temat, som formulerats av Vetenskapsrådet, återspeglar ett synsätt på förskolan som tidig insats, som socialt rum för påverkan, som återkommer både nationellt och internationellt, och med tydlig historisk kontinuitet (Jönsson, Sandell \& Tallberg Broman, 2013; SOU 2010:64, Tallberg Broman \& Balldin, 2010). Det motsvarar ett utbildnings- och forskningsområde, som i hög grad understötts av en under senare år påtagligt förstärkt aktör inom skolans och skolforskningens område: OECD (OECD, 2016, 2017).

Bristande måluppfyllelse på senare skolstadier har påverkat satsningar på förebyggande och på de yngsta barnen och på en utbyggd förskola i många länder. Stora internationella undersökningar har visat att en förskola av hög kvalitet, med tydliga pedagogiska program, har såväl lång- som kortsiktigt positiva effekter, speciellt för barn från missgynnade förhållanden och för barn i behov av särskilt stöd. (Havnes \& Mogstad, 2009; Sylva, Melhuish, Simmons, Siraj-Blatchford \& Taggart, 2010). Genom nationalekonomen Heckmans studier (exempelvis Heckman, 2006) fick förskola som tidig insats ett starkt stöd. Heckman visade hur lönsam förskolan är, under förutsättning att den håller hög kvalitet. Rubriken för vår kunskapsöversikt Förskola tidig intervention sammanfattar denna förståelse för förskolans möjligheter förutsatt en god kvalité. Begreppet "tidiga insatser" har dock i senaste årens utbildningspolitik och olika satsningar i Sverige snarare motsvarats av uppmärksamhet och satsningar på årskurs 1, 2 och 3 i den obligatoriska skolan än på förskola.

\section{Praktiknära och kompetensutvecklande: Forskarskolor}

2007 inleddes regeringens satsning på forskarskolor för lärare. Förskollärarna ingick från början inte i satsningen. De har i många satsningar på forskning och på kompetensutveckling av verksamma lärare hela tiden följt några steg 
efter övriga lärargrupper. Ett större antal uppvaktningar, skrivelser och debattartiklar har därför ingått i professurens arbetsinnehåll.

Utvärderingen av första gruppen forskarskolor innefattade såväl kritik mot satsningen, som positiva bedömningar. Utvärderingen visade att deltagarna, kommunerna och forskarskolorna på det stora hela är positiva till satsningen (Högskoleverket, 2012). Kritiken kom dock att bli mest uppmärksammad. För även om de som deltog var positiva till satsningen, konstaterade Högskoleverket i sin rapport att bara hälften av de forskarutbildade lärarna kunde tänka sig att jobba kvar i skolan. De personer som man hoppades skulle återvända för att utveckla arbetet i skolan, såg sin framtid inom akademin i stället. Naturligtvis var SKL tydlig i sin kritik. I satsningarna deltog också bara ett fåtal kommuner. I högskoleverkets rapport riktas också kritik mot huvudmännen, eftersom de i många fall varken tycktes ha tänkt igenom vad de vill ha ut av satsningen eller hur de ska ta vara på de forskarutbildade lärarnas kompetens när de är klara med sin forskarutbildning. Det hade saknats en dialog mellan huvudmännen och forskarskolorna om hur behoven ser ut $\mathrm{i}$ skolorna. Forskarskolorna har bestämt innehållet och sedan har lärarna fått söka. Om huvudmännen hade varit mer aktiva $i$ att beskriva vilken typ av kunskap de behövde, kanske forskarskolesatsningen utvecklats annorlunda (Högskoleverket, 2012).

Att $\mathrm{i}$ en förhållandevis liten forskningsmiljö som vår, med få doktorandanställningar, få en möjlighet till utökat antal doktorander inom professurens område startade en febril aktivitet med ansökningar och nätverksbildande. Detta kom att få stor betydelse. Den första beviljade ansökan om forskarskola var inriktad mot doktorsexamen och finansierades av Vetenskapsrådet. Dess inriktning var mot Barndom, lärande och ämnesdidaktik, med fokus på kunskapsutveckling relaterad till förskolan och grundskolans tidigare år. Rubriceringen vi valt, med framhävande av barndom, syftade till en problematisering av barns lärande och förskolans ämnesdidaktik genom ett kontextualiserande barndomsperspektiv. Detta kom dock inte att illustreras $i$ någon större utsträckning $\mathrm{i}$ avhandlingarna, som framför allt fokuserade lärandes hur-fråga (Williams, Sheridan \& Arnqvist, 2013; Åkerblom, 2016 ). Forskarskolan baserades på ett nationellt samarbete mellan fem högskolor och universitet (Kristianstad, Göteborg, Linköping, Karlstad och Malmö, som var initierande och ansvarigt) och startade 2008. Den ledde till sju avhandlingar inom forskningsområdet, som senare lett vidare till andra projekt och fört området vidare.

Den andra, med uppstart 2010, och den tredje 2011 var finansierade genom regeringens satsning på forskarskolor med licentiatexamen som mål för förskollärare och lärare. De representerar, som det stod i utlysningen, ”en del i regeringens ambitioner att bygga upp skolans och förskolans kunskapsbas och öka antalet lärare och förskollärare med utbildning på forskarnivå i skolan 
och förskolan" (Pramling \& Tallberg Broman, 2013). Två ytterligare forskarskolor med näraliggande tema och i samverkan mellan olika lärosäten har sedan initierats och nu med ansvar och placering vid Göteborgs universitet. Forskarskolornas mer styrda fokus, mot exempelvis språk och matematik efter de två första öppet formulerade, uttrycker också den ökade styrningen från statsmakterna vad gäller förskole- och skolforskning inklusive forskarskolorna (Akerblom, 2016; Talberg Broman, 2017). Ett trettiotal licentiatavhandlingar inom förskolans område, med olika fokus men i huvudsak relaterade till barns lärande, har under dessa år publicerats eller är pågående. En stor andel av dessa licentiander har också fortsatt sina studier till doktorsexamen.

I utvärderingar betonas att vissa förutsättningar bör vara uppfyllda för att forskarskolorna ska kunna nå de uppställda målen. För oss tydliggjordes vikten av att ha legitimitet för forskarskolan på de olika lärosätena med god förankring $\mathrm{i}$ etablerade strukturer, att ha tydliga och väl kommunicerade mål, att ha god och likvärdig finansiering mellan lärosätena, att ha handledare med kompetens inom forskarskolans område samt att det utvecklas en tydlig ledningsstruktur och ledningsgrupp.

Detta överensstämde i stort med de erfarenheter som professor Christina Gustavsson, ansvarig, och jag kunde summera vid en halvtidsutvärdering (Norskt Forskningsråd, 2013) av satsningen på forskarskola för lärarutbildningen i Norge (NAFOL). Forskarskolan skulle stödja relevant forskning av hög kvalitet, skapa en nationell plattform för att öka FoU- kompetensen och stärka samarbetet mellan lärosätena. Vid tiden för utvärderingen hade drygt 100 stipendiater antagits. Det var en nationell satsning, med delaktighet från alla lärosäten. Några år senare utannonserades också i Sverige forskarskolemöjlighet vad gäller lärarutbildningarna, $i$ en något annan modell (Vetenskapsrådet, 2017).

Forskarskolorna har en organisationsform som gör det möjligt att ta tillvara de kunskaper och erfarenheter inom forskningsfältet som är spridda över landet. Därmed kan man skapa starkare forsknings/kunskapsmiljöer till gagn för fortsatt utveckling inom området. Våra forskarskolor kom att få stor betydelse för vår interna, förhållandevis lilla, forskningsmiljö genom det nätverk de erbjöd, både av forskarstuderande, handledare och seniora forskare. I utvärderingar har perspektivet vad forskarskolorna inneburit för lärosätenas forskningsmiljöer varit föga uppmärksammat. Det var heller inte forskarskolorna syfte, men nationellt stärker de förskolans/skolans vetenskapliga grund och bidrar till akademisering av lärarutbildningarna, dels genom relevant forskning för utbildningarnas forskningsanknytning, dels för att en stor andel av de studerande fortsatt inom akademin. De är dock ännu för få.

Bristen på forskarutbildade förskollärarutbildare med kompetens inom det förskolepedagogiska området lyfts nu som ett hinder för den utbyggnad av 
förskollärarutbildningar som vore angelägen i lärarbristens tid. SKL (2018) konstaterar i rapport om skolans problematiska rekryteringssituation att det skulle behövas att mer än dubbelt så många påbörjade en lärarutbildning de kommande åren. Störst väntas bristen bli på förskollärare, yrkeslärare och ämneslärare (SKL, 2018, s. 16). SKL konstaterar dock att bristen på forskarutbildade lärare innebär att den utökning av utbildningen som krävs inte är möjlig:

\begin{abstract}
När det gäller förskollärare finns inte kapaciteten att utbilda förskollärare i den omfattning som efterfrågas (om målet är att behålla dagens andel förskollärare som ligger på drygt 40 procent). Den kraftiga expansion av platser som skulle behövas för att täcka behoven kan inte genomföras utan negativa konsekvenser för utbildningens kvalitet. Det handlar inte minst om att det saknas förskollärarutbildare som har forskarutbildning och kompetens inom det förskolepedagogiska området (SKL, 2018, s. 35).
\end{abstract}

Forskarskolorna har kommit att ge positiva bidrag till andelen forskarutbildade vid förskollärarutbildningen. Det är lärosätena som kan ses som de direkta avnämarna och vinnarna av forskarskolornas arbete, medan kommunerna, som varit medfinansiärer, snarast fått en indirekt utdelning av sina satsningar. Det ekonomiska ansvaret har varit felaktigt utformat.

\title{
Kommundoktorander, nya forskningsaktörer och samverkansprojekt
}

De satsningar som representeras av kommundoktorander har inneburit en koppling direkt till den tilltänkta framtida arbetsplatsen (Skans, 2011; Westlund, 2011). Kommunen har varit delaktig $\mathrm{i}$ att formulera angelägna forskningsfrågor och har också följt doktoranderna, och - efter hand utvecklat relevanta anställningar kopplade till utvecklingsarbete i kommunerna.

Samverkan mellan lärosätet och kommunerna med gemensamma projekt har också utvecklats påtagligt under senare år, där kommunen exempelvis delfinansierar forskning och forsknings- utvecklingsarbete kring för dem angelägna frågor (Persson \& Tallberg Broman, 2018; Tallberg Broman \& Persson, 2018). Delaktighet i projekt har blivit ett argument för arbetsgivaren för att lyfta sina förskolor och skolor, och attrahera förskollärare och lärare i lärarbristens tid. Nya aktörer och fristående institut har också fătt stor betydelse. Under rubriken "Forskningssamarbete ska lyfta Eslövs förskolor" refereras till det fristående forskningsinstitutet, IFOUS, och dess Malmöbaserade program: "Flerstämmig undervisning i förskolan" (V allberg Roth, Holmberg, Palla, Stensson \& Tallberg Broman, 2018). Kommuner, fristående forskningsinstitut och internationella aktörer bidrar $i$ hög grad till utveckling av forskning och forskning- och utvecklingsprojekt inom området med hög sambälls- och professionsrelevans. 


\section{AVSLUTNING}

Jag lämnade min professur årsskiftet 2011/2012, och har sedan dess varit fortsatt anställd som forskare/senior professor. Hela tidsperioden har utgjort underlag för min artikel. Professuren hade inrättats 1999. Ett år innan hade förskolan fått sin första läroplan och tre år innan hade förskolan överförts till utbildningsdepartementet. Den rubricerades som pedagogik med inriktning på barns utveckling och lärande. Begreppsparet återkommer i förskolans styrdokument, men generellt beskriver perioden, både i forskning och forskningsoch utbidningspolitik, en förskjutning mot lärande och senare även mot undervisning (Tallberg Broman, 2015).

Professuren utannonserades åter under en något förändrad rubricering: "Professor i pedagogik med inriktning mot yngre barns lärande och utbildning”. Rubriceringen fångar upp en pågående förändring, där förskolan nu formeras som ett socialt rum för utbildning, undervisning och lärande. Vallberg Roth (2013) beskriver $i$ en analys av riktlinjer i de nordiska förskolorna, en trend som rör sig från omsorg och trygghet till lärande och utvärdering. Centrala tema $\mathrm{i}$ förskolans innehåll är mindre synliga, och är också av mindre intresse för de på förskolans och skolans område viktiga nationella forskningsfinansiärerna.

På Vetenskapsrådet avspeglas detta $\mathrm{i}$ vad som inbegrips i utbildningsvetenskap, det vill säga det som kan finansieras. Områden som fostran och bildning, som ligger nära den förskolepedagogiska kunskapstraditionen och som ingått tidigare, inkluderas nu inte längre $i$ defiitionen av utbildningsvetenskaplig forskning. På Vetenskapsrådets hemsida i april 2018 anges innebörden av begreppet utbildningsvetenskap: "Utbildningsvetenskap handlar om forskning om lärande, kunskapsbildning, utbildning och undervisning" (Vetenskapsrådet, 2018). I Vetenskapsrådets kartläggning av utbildningsvetenskaplig forskning år 2010 uppges den tidigare vidare definitionen: "Utbildningsvetenskaplig forskning är forskning om bildning, utbildning, undervisning, fostran och lärande" (Vetenskapsrådet 2011b, s. 12). Den senast inrättade forskningsfinansiären för förskole- och skolområdet, Skolforskningsinstitutet, och dess uppdrag illustrerar förändringen. Ökad styrning och avgränsning av forskningfokus hos de få nationella forskningsfinansiärerna innebär en problematik för att kunna stärka den vetenskapliga grunden i de skolformer, som har ett mer komplext uppdrag, innehåll och professionsgrundade forskningsfrågor.

Min professurs inriktning på att stärka forskning relaterad till barns utveckling och lärande är fortsatt relevant, här råder ett starkt drag av kontinuitet, men hindren har nu en annan karaktär än brist på forskare och forskarkompetens. 
Avslutningsvis: Kontexten för min professur var en högskola som framhöll förankring och samverkan med det lokala, med den mångfaldsrika Malmöregionen. Likvärdighet, jämlikhet och social hållbarhet har utgjort angelägna och centrala frågor både i undervisning, forskning och samverkan. Sista ordet går till tidigare chefen för lärarutbildningen, och den som initierade min professur, Olle Holmberg och den Skolkommitté han var huvudsekreterare för:

När det gäller jämlikhetsfrågor föreslår vi att ett europeiskt resurscentrum inrättas, förlagt till Sverige. Detta centrum ska, enligt förslaget, arbeta med utveckling och forskning rörande barns och ungdomars likvärdiga möjligheter i barnomsorg, skola och skolbarnsomsorg (SOU 1997:121, s. 12).

Det förslaget har haft ett antal år på sig att förverkligas. Det är utmärkt dags $\mathrm{nu}$ - uppdatera formuleringen och förlägg detta centrum till Malmö.

\footnotetext{
NOTER

${ }^{1}$ Olle Holmberg, som tidigare varit huvudsekreterare i den statliga

"Skolkommittén", utsågs 1998 till ansvarig för lärarutbildning vid den nybildade högskolan i Malmö.

2 Såväl "Lärarexamen för förskolan" (2001-2010) som "Förskollärarexamen”, den nu-varande från år 2011, kräver sju terminers heltidsstudier (3,5 år).

3 Torsten Husén innehade denna professur åren 1956-1971.

4 Parallellt med att det inrättades en professur i "praktisk pedagogik" 1962, så fick professor Ingvar Johannesson en professur i Lund som var i "pedagogik". Där hade professor Gudmund Smith två år tidigare fått en professur i "psykologi", i det tidigare sammanhållna ämnet.

${ }^{5}$ Regeringen anförde i propositionen Forskning och innovation (prop. 2012/2013: 30) att forskningsresultat från en mängd olika vetenskapliga discipliner bör bevakas och värderas ur ett relevansperspektiv för skolan och förskolan. I propositionen anfördes: "Det är viktigt att forskningsresultat med relevans för skolan och förskolans verksamhet systematiskt vägs samman och sprids till dem som är verksamma $i$ skolan och förskolan, så att kunskaperna omsätts i praktiken i undervisningen och i utformningen av stödet till eleverna men också i det pågående skolutvecklingsarbetet (s.101). 2015-01-01 inrättades så Skolforskningsmyndigheten. ${ }^{6}$ 2013-11-21 beslöt regeringen att ge Vetenskapsrådet i uppdrag att ansvara för genomförandet av validerade kartläggningar av svenska och internationella forskningsresultat med relevans för, som så kallat praktiskt arbete i skolväsendet. En av dessa var Förskola tidig intervention.

${ }^{7}$ Lärarutbildningskommittén (LUK) föreslog år 1999 att utbildningsvetenskap skulle etableras som ett nytt vetenskapsområde med egen, öronmärkt, finansiering av forskningsstöd till lärosäten med lärarutbildning, Detta för att stärka lärar-
} 
utbildningens forskningsanknytning. (Vetenskapsrådet 2011a, s. 8, 14.). Regeringen avslog förslaget om ett nytt vetenskapsområde, och föreslog istället en särskild kommitté för utbildningsvetenskap.

\section{REFERENSER}

Agevall, O. \& Olofsson, G. (2014). Tensions between academic and vocational demands. I J.-C. Smeby \& M. Sutphen (Red.). From Vocational to Professional Education: Educating for Social Welfare (s. 26-49). London and New York: Routledge.

Bjerstedt, Å. (1999). Pedagogikavhandlingar i Sverige under trettio år 1969-1998. Malmö: Pedagogisk dokumentation, Nr 127.

Comenius, J., A. (1892). Stora undervisningsläran. Göteborg: Wettergren \& Kerber.

Dahlbeck, J. \& Tallberg Broman, I. (2011). Ett bättre samhälle genom pedagogik: om högre värden och barnet som budbärare. I P. Williams \& S. Sheridan: Barns lärande $i$ ett livslångt perspektiv (s. 202-214.). Stockholm: Liber.

Dir. 2007:103. En ny lärarutbildning. Stockholm: Utbildningsdepartementet.

Eilard, A. (2008). Modern, svensk och jämställd. Om barn, familj och omvärld i grundskolans läseböcker (Doktorsavbandling). Malmö: Malmö högskola.

Eilard, A. (2009). Förändrade genusmönster i grundskolans läseböcker. I I. Wernersson (Red.). Genus i förskola och skola. Förändringar i policy, praktik och perspektiv (s. 121-137). Göteborg: Göteborgs universitet.

Fridolin, G. \& Hallengren, L. (2017, 21/3). S och MP: Vi investerar kvalitet i förskolan. Svenska dagbladet. Hämtad från: https://www.svd.se/s-och-mp-viinvesterar-i-kvalitet-i-forskolan

Fröbel, F. (1892). Kommt, lasst uns unsern kindern leben. Band 1-3. Berlin: Volk und Wissen.

Gieryn, T. (1983). Boundary-work and the demarcation of science from nonscience: Strains and interests in professional ideologies of scientists. American Sociological Review, 48(6), 781-95.

Hammarström-Lewenhagen, B. (2016). Förskolans århundrade. Malmö: Gleerups.

Havnes, T. \& Mogstad, M. (2009). No child left bebind: Subsidized child care and children's long-run outcomes. Discussion Papers No. 582, May 2009. Statistics Norway, Research Department.

Heckman, J. (2006). Skill Formation and the economics of investing in disadvantaged children. Science, 312(5782), 1900-1902.

Högskoleverket (2012). Utvärdering av forskarskolor för lärare. Rapport 2012:9 R.

Jönsson, I., Sandell, A. \& Tallberg Broman, I. (2013). Change or paradigm shift in the Swedish preschool? Article_journal Sociologia, Problemas e Práticas. 69, 47-62. 


\section{INGEGERD TALLBERG BROMAN}

Korsvold, T. (2008). For alle barn. Barnehagens framväxt $i$ velfersstaten (3. uppl.). Oslo: Abstrakt forlag.

Lefebvre, H. (1991). The Production of Space. Oxford: Blackwell.

Lindberg, L. \& Berge, B-M. (1988). Pedagogik som vetenskap - vetenskap som pedagogik. Lund: Studentlitteratur.

Linné, A. (2014). Några vägval i lärarutbildningen historia. Vägval $i$ skolans historia. Tidskrift för svensk utbildningshistoria. Hämtad från: https://undervisningshistoria.wordpress.com/2014/12/07/nagra-vagval-ilararutbildningens-historia/

Lärarnas Tidning (2010). Utbildningsvetenskapliga kommittén fär ny inriktning. Hämtad från: https:/ / lararnastidning.se/utbildningsvetenskapliga-kommitten-far-nyinriktning/

Löf, C. (2011). Med livet på schemat. Om skolämnet livskunskap och den riskfyllda barndomen (Doktorsavhandling). Malmö: Malmö högskola.

Myles, J. \& Pierson, P. (2001). The Comparative Political Economy of Pension Reform. I P. Pierson, (Red.). The new politics of the welfare state. (s. 305-333) Oxford: Oxford University Press.

Norskt Forskningsråd (2013). Nasjonal forskerskole for larerutdanningene (NAFOL). En utvärdering efter halva tiden. Oslo: Divisjon for samfunn og helse.

OECD (2016). What are the benefits from early childhood education? Education Indicators in Focus. No 42. Paris: OECD.

OECD (2017). Starting Strong 2017: Key OECD Indicators on Early Childhood Education and Care. Paris: OECD.

Persson, S. \& Tallberg Broman, I. (2002). "Det är ju ett annat jobb”. Förskollärare, grundskollärare och lärarstuderande om professionell identitet i konflikt och förändring. Pedagogisk Forskning i Sverige, 7(4), 257-278.

Persson, S. \& Tallberg Broman, I. (2015). Det professionella uppdraget. Del 2.

Presentation vid Vetenskapsrådets resultatdialog. Malmö: Malmö högskola.

Persson, S. \& Tallberg Broman, I. (2017). Early childhood education and care as a historically located place - the significance for parental cooperation and the professional assignment. Nordic Journal of Studies in Educational Policy, 3(2), 189-199.

Persson, S. \& Tallberg Broman, I. (2018). Dilemma i förskollärares uppdrag. En studie mot bakgrund av ökad psykisk ohälsa bland förskollärare. Hämtad 180722 från: https://www.mah.se/Forskning/Sok-pagaende-forskning/Dilemma-iforskollarares-uppdrag---en-studie-mot-bakgrund-av-okad-psykisk-ohalsa-hosforskollarare/

Pestalozzi, J. H. (1890). Lienhard och Gertrud. En bok för folket. Göteborg: Wettergren \& Kerber. 
Pramling Samuelsson, I. \& Tallberg Broman, I. (Red.) (2013). Barndom, lärande och ämnesdidaktik. (1. uppl.) Lund: Studentlitteratur.

Rousseau, J. J.(1892). Emile eller om uppfostran. Göteborg: Wettergren och Kerber.

Rubinstein-Reich, L. (2017). Det ständigt pågående utvecklingsarbetet. I L. Rubinstein Reich, I. Tallberg Broman \& A-C. Vallberg Roth (Red.). Professionell yrkesutörning i förskola. (s. 261-319). Lund: Studentlitteratur.

Sernhede, O. \& Tallberg Broman, I. (2011). Förord till Tema: Välfärdsstat i omvandling: reglerad barndom - oregerlig ungdom? Educare, 2, 7-11.

Sernhede, O. \& Tallberg Broman, I. (2014) (Red.). Segregation, utbildning och ovanliga processer. Stockholm: Liber.

SFS 1842:19. Folkskolestadgan. Kongl. Maj:ts Nådiga Stadga angående Folkundervisningen i Riket.

Skans, A. (2011). En flerspråkig förskolas didaktik i praktiken. Malmö: Malmö högskola.

SKL (2018). Skolans rekryteringsutmaningar. Lokala strategier och exempel. Stockholm: SKL.

SOU 1952:33 Den första lärarbögskolan: betänkande / utgivet av 1946 års skolkommission. Stockholm: Eclesiastikdepartementet.

SOU 1960:33 Förskollärarutbildningens organisation. Betänkande avgivet av 1958 års förskollärarutbildning. Stockholm: Socialdepartementet.

SOU 1972:26-27. Förskolan, Del 1 och 2. Betänkande avgivet av 1968 års barnstugeutredning. Stockholm: Socialdepartementet.

SOU 1975:67 Utbildning i samspel. Betänkande frän 1968 års barnstugeutredning. Stockholm: Socialdepartementet.

SOU 1997:121. Skolfrågor: Om skola $i$ en ny tid. Stockholm: Fritzes.

SOU 2008:109. En hållbar lärarutbildning. Betänkande av utredningen om en ny lärarutbildning. Stockholm: Fritzes.

SOU 2010: 64. Se tidiga tecken" - forskare reflekterar över sju berättelser frän förskola och skola. Delbetänkande av utredningen om översyn av skolans arbete med utsatta barn. Stockholm: Fritzes.

SOU 2018: 19. Forska tillsammans - samverkan för lärande och förbättring. Stockholm: Nordstedts juridk.

Sylva, K., Melhuish, E., Simmons, P., Siraj-Blatchford, I. \& Taggart, B. (2010). Early childhood matters: Evidence from the effective pre-school and primary education project. London: Routledge.

Tallberg Broman, I. (1991). När arbetet var lönen. En kvinnohistorisk studie av barnträdgårdsledarinnan som folkuppfostrare (Doktorsavhandling). Malmö: Almqvist \& Wiksell International. 


\section{INGEGERD TALLBERG BROMAN}

Tallberg Broman, I. (2009). Mamma, pappa, förskolebarn. Om förskolan som jämställdhetsprojekt. I I. Wernersson (Red.). Genus i förskola och skola. Om policy, praktik och perspektiv (s. 61-83). Göteborg: Göteborg Studies in Education.

Tallberg Broman, I. (2015). Förskola till stöd för barns utveckling och lärande. I I. Tallberg Broman, A-C. Vallberg Roth, L. Palla \& S. Persson. Förskola tidig intervention (s. 16-59). Stockholm: Vetenskapsrådet.

Tallberg Broman, I. (2017). Att forskningsbasera förskolan - språk, matematik, naturvetenskap. I L. Rubinstein Reich, I.Tallberg Broman \& A-C. Vallberg Roth (Red.). Professionell yrkesutörning i förskola. (s. 111-129). Lund: Studentlitteratur.

Tallberg Broman, I. et al. (2009). Temanummer: En gränsöverskridande skola: Olika former av styrning och reglering i barndomen. Educare, 2-3.

Tallberg Broman, I. \& Balldin, J. (2010). Förskolan och de utsatta barnen utmaningar och möjligheter. I "Se tidiga tecken" - forskare reflekterar över sju berättelser från förskola och skola. SOU 2010:164. Delbetänkande av utredningen om översyn av skolans arbete med utsatta barn. (s. 79-100). Stockholm: Fritzes.

Tallberg Broman, I. \& Persson, S. (2018). Nationellt uppdrag- lokala förutsättningar. Rapport 1 i projektet: Dilemma i förskollärares uppdrag. En studie mot bakgrund av ökad psykisk obälsa bland förskollärare. Malmö: Malmö universitet.

Tallberg Broman, I., Vallberg Roth, A-C., Palla, L. \& Persson, S. (2015). Förskola tidig intervention. Delrapport från SKOLFORSK-projektet. Stockholm: Vetenskapsrådet.

Trondman, M. (2009). Slutkommentar: Mångkontextuella och gränsöverskridande läroprocesser - Om barn som självreglerande och egenansvariga subjekt. Educare, 2-3, 241-298.

UNESCO (2007). The UN decade of education for sustainable development, 20052014. Paris: UNESCO.

Vallberg Roth, A-C. (2013). Nordisk komparativ analys av riktlinjer för kvalitet och innehäll iförskolorna. Oslo: Kunskapsdepartementet.

Vallberg Roth, A-C., Holmberg, Y., Palla, L., Stensson, C. \& Tallberg Broman, I. (2018). Flerstämmig undervisning och sambedömning. Malmö: Malmö universitet.

Vetenskapsrådet (2011a). Inventering av svensk, utbildningsvetenskaplig forskning. Rapport 2: 2011. Stockholm: Vetenskapsrådet.

Vetenskapsrådet (2011b). Utbildningsvetenskap och utbildningsvetenskapliga kommittén. Stockholm: Vetenskapsrådet.

Vetenskapsrådet (2017). Forskarskola för lärarutbildare. Stockholm: Vetenskapsrådet.

Vetenskapsrådet (2018). Utbildningsvetenskap. Hämtad från: https://www.vr.se/amnesomraden/amnesomraden/utbildningsvetenskap.4.12fff 4451215cbd83e4800021012.html

Wernersson, I. (2009). (Red.). Genus i förskola och skola. Förändringar i policy, perspektiv och praktik. Göteborg: Göteborgs universitet. 
Westlund, K. (2011) Pedagogers arbete med förskolebarns inflytande. En demokratididaktisk studie. Malmö: Malmö högskola.

Williams, P., Sheridan, S. \& Arnqvist, A. (2013). Dimensionernas kvalitet. I I. Pramling Samuelsson \& I. Tallberg Broman (Red.). Barndom, lärande, ämnesdidaktik (s. 211-227). Lund: Studentlitteratur.

Åkerblom, A. (2016). Med förskolepraktik i fokus. Kunskapsbidrag och erfarenheter av de nationella forskarskolorna för verksamma förskollärare, FöFoBa och FoBaSM. Malmö: Rapporter om utbildning. 